\title{
Two Receptor-Like Genes, Vfa1 and Vfa2, Confer Resistance to the Fungal Pathogen Venturia inaequalis Inciting Apple Scab Disease
}

\author{
Mickael Malnoy, ${ }^{1}$ Mingliang Xu, ${ }^{2}$ Ewa Borejsza-Wysocka, ${ }^{1}$ Schuyler S. Korban, ${ }^{2}$ and \\ Herb S. Aldwinckle ${ }^{1}$ \\ ${ }^{1}$ Department of Plant Pathology, Cornell University, Geneva, NY 14456, U.S.A.; ${ }^{2}$ Department of Natural Resources and \\ Environmental Sciences, 310 ERML, University of Illinois, 1201 West Gregory Drive, Urbana 61801, U.S.A.
}

Submitted 27 July 2007. Accepted 23 November 2007.

\begin{abstract}
The $V f$ locus, originating from the crabapple species Malus floribunda 821, confers resistance to five races of the fungal pathogen Venturia inaequalis, the causal agent of apple scab disease. Previously, a cluster of four receptor-like genes, $V f a 1, V f a 2, V f a 3$, and $V f a 4$, was identified within the $V f$ locus. Because the amino-acid sequence of $V f a 3$ is truncated, it was deemed nonfunctional. In this study, each of the three full-length $V f a$ genes was introduced into a plant cloning vector, pCAMBIA2301, and used for Agrobacterium-mediated transformation of two apple cultivars, Galaxy and McIntosh, to assess functionality of these genes and to characterize their roles in resistance to $\mathrm{V}$. inaequalis. Transformed apple lines carrying each of $V f a 1, V f a 2$, or Vfa4 were developed, analyzed for the presence of the transgene using polymerase chain reaction and Southern blotting, and assayed for resistance to apple scab following inoculation with $V$. inaequalis. Transformed lines expressing $V f a 4$ were found to be susceptible to apple scab, whereas those expressing either $V f a 1$ or $V f a 2$ exhibited partial resistance to apple scab. Based on Western blot analysis as well as microscopic analysis of plant resistance reactions, the roles of $V f a 1$ and $V f a 2$ in apple scab disease resistance response are discussed.
\end{abstract}

Additional keywords: Vf gene.

Plant-pathogen interactions, particularly those involving biotrophic pathogens, require specific recognition between resistance $(R)$ gene products and pathogen avirulence $(A v r)$-dependent "elicitors." This recognition triggers a chain of signal transduction events, leading to an active defense response.

In the past decade, intensive efforts have pursued the identification of plant $R$ genes, and more than $50 R$ genes have been isolated and characterized from various plant species. These $R$ genes confer resistance to bacterial, viral, fungal, oomycete, nematode, or insect attack (Dangl et al. 2001). Despite their

M. Malnoy and M. Xu are co-first authors on this article.

Current address of M. Xu: National Maize Improvement Center of China, China Agricultural University, 2 West Yuanmingyuan Road, Beijing, 100094, Peoples Republic of China.

Corresponding authors: S. S. Korban; E-mail: korban@uiuc.edu; and H. S. Aldwinckle; E-mail: hsa1@ cornell.edu

Current address of M. Malnoy: IASMA Research Center Via E. Mach 1, 38010 San Michele all'Adige (TN), Italy. roles in resistance against a wide range of pathogens, $R$ genes isolated so far share various conserved domains, including serine-threonine protein-kinase, nucleotide-binding site (NBS), and leucine-rich repeat (LRR) domains, and fall into four classes. The largest class of $R$ genes encodes an NBS and multiple C-terminal LRR (NBS-LRR); this is exemplified by the $N$ gene in tobacco, the RPS2, RPM1, and RPP5 genes in Arabidopsis, and the $L 6$ and $M$ genes in flax. Tomato $C f$ genes represent the second class of $R$ genes, and they consist of multiple $\mathrm{N}$-terminal LRRs and transmembrane (TM) domains (Dangl et al. 2001). The tomato Pto gene, composed of only a proteinkinase domain, is regarded as the third class; while the rice $\mathrm{Xa} 21$ gene, featuring both extracellular LRRs and a TM protein kinase, belongs to the fourth class (Song et al. 1995). A comprehensive analysis of the Arabidopsis genome provides insight into the distribution of different $R$ gene classes within that genome. There are approximately 150 homologous sequences of the NBS-LRR class, and another 30, 174, and 50 genes resembling $C f, X a 21$, and Pto genes, respectively.

Plants have evolved sophisticated mechanisms to develop new resistance specificities to perceive novel Avr products from the everchanging pathogen populations. Point mutations, short sketch duplications or deletions, alterations of LRR units, and even transposon-like element inserts can contribute to initial genetic variations of $R$ genes (Xu and Korban 2004). Reassortment of initial genetic variations in alleles or family members via recombination creates a vast repertoire of resistance specificities (Hulbert et al. 2001). Divergent selection enables those variants with advantageous ligand-binding affinities to increase in a population. Analysis of solvent-exposed residues in the consensus sequence xxLxLxx in the LRR domain shows enhanced ratios of nonsynonymous to synonymous substitutions (Bergelson et al. 2001; Parniske et al. 1997; Wang et al. 1998). This suggests that the LRR domain acts as a receptor to recognize pathogen-secreted ligands under diversified selection (Michelmore and Meyers 1998). Direct binding recently has been observed between the LRR domain of the resistance gene $\mathrm{Pi}$-ta protein and the cognate pathogen AvrPita protein in rice (Jia et al. 2000).

The apple Malus $\times$ domestica Borkh. has become a model woody perennial angiosperm for genomic research due to its economic importance, relatively small genome size (750 $\mathrm{Mb} /$ haploid), availability of over 300,000 expressed sequence tags (EST), bacterial artificial chromosome (BAC) libraries, genetic maps, first-draft physical map, and a robust genetic transformation system (Aldwinckle et al. 2003; Han et al. 2007; Liebhard et al. 2003; Newcomb et al. 2006; Tatum et al. 
2005; Xu and Korban 2002a; Xu et al. 2001). Most cultivated apple lines are diploids $(2 n=34)$, self-incompatible, open-pollinated, and display a juvenile period of 6 to 10 years or more (Korban and Chen 1992). Apple scab, caused by the fungal pathogen Venturia inaequalis (Cooke) G. Winter, is one of the most serious diseases of apple (Bénaouf and Parisi 2000). Almost all apple cultivars grown commercially around the world are susceptible to this disease. A scab-resistance locus $V f$ has been identified in a clone of the wild species, Malus floribunda 821 , and has been widely bred with susceptible commercial apple cultivars (Korban 1998). Currently, $V f$ resistance is present in more than 70 scab-resistant cultivars (Janick et al. 1996). The $V f$ locus confers resistance to five races of $V$. inaequalis but not to races 6 and 7, recently identified in Europe (Durel et al. 2003; Guerin and Le Cam 2004).

A number of scab resistance genes have been mapped onto the apple genome, with $V f$ (Maliepaard et al. 1998), $V a$, and $V b$ (Hemmat et al. 2003) mapping to linkage group (LG)1; Vbj (Gygax et al 2004), Vh2, Vh4, and Vh8 (Bus et al. 2005a,b), and $V r 2$ (Patocchi et al. 2004) mapping to LG2; and $V g$, $V b$, and $V m$ mapping to LG12 (Calenge et al. 2004, Erdin et al. 2006, Patocchi et al. 2005). Many quantitative trait loci (QTL) for scab resistance also have been mapped to approximately half of the linkage groups of apple (Calenge et al. 2004; Durel et al. 2003; Liebhard et al. 2003). Some of the major genes and QTL have been mapped to the same regions on the apple genome, suggesting the presence of gene clusters. $R$ gene clusters are common in hosts infected by (hemi-) biotrophic pathogens (Parlevliet 2002), and these have been identified in many crop-disease systems (Michelmore and Meyers 1998; Young 2000).

To date, only the $V f$ locus has been analyzed in detail in apple, and it has been identified as a complex locus containing four paralogs (Vinatzer et al. 2001; Xu and Korban 2002b). Vinatzer and associates (2001) identified this cluster of four genes at the $V f$ locus from a BAC library of apple cv. Florina using chromosome walking, while $\mathrm{Xu}$ and Korban (2002b) cloned these four $V f$ paralogs from GoldRush and $M$. floribunda 821 BAC libraries via chromosome landing. Three of the paralogs, Vfal, Vfa2, and $V f a 4$, have intact open reading frames (ORF), whereas $V f a 3$ is an obvious pseudogene (Vinatzer et al. 2001; Xu and Korban 2002b). Differential expression has been observed among the four $V f$ paralogs during leaf development, whereby $V f a 1$, Vfa2, and $V f a 3$ are active in immature leaves but barely detectable in mature leaves, whereas Vfa4 is active in immature leaves and highly expressed in mature leaves. One of these $V f$ paralogs, HcrVf2 (syn. Vfa2), was transformed into susceptible apple cul-

\section{McIntosh McIntosh $V f a 4$ TMcI-1577}
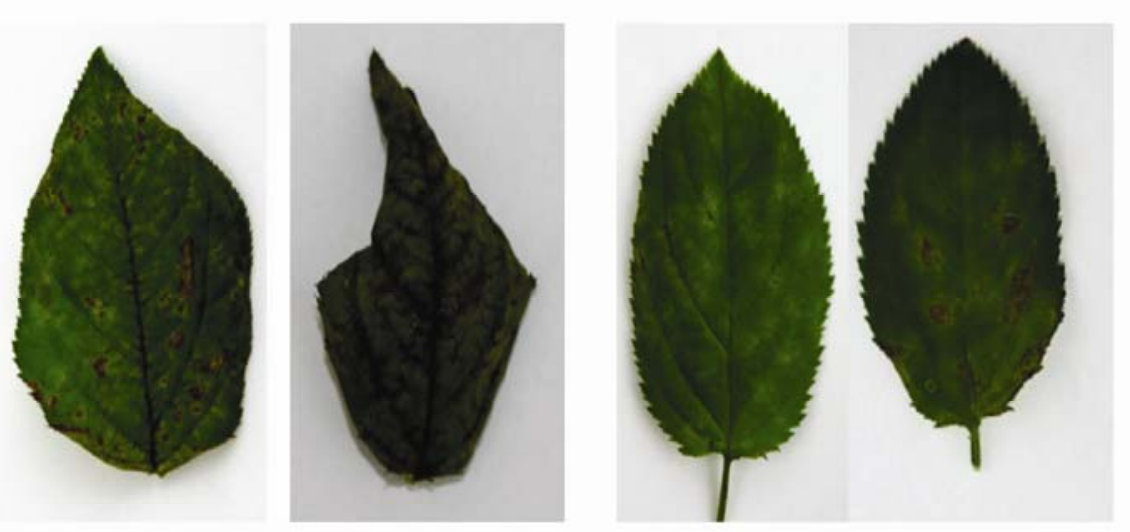

\section{McIntosh $V f a 2$ TMcI-1580}

\section{McIntosh $V f a 1$ TMcI-1578}

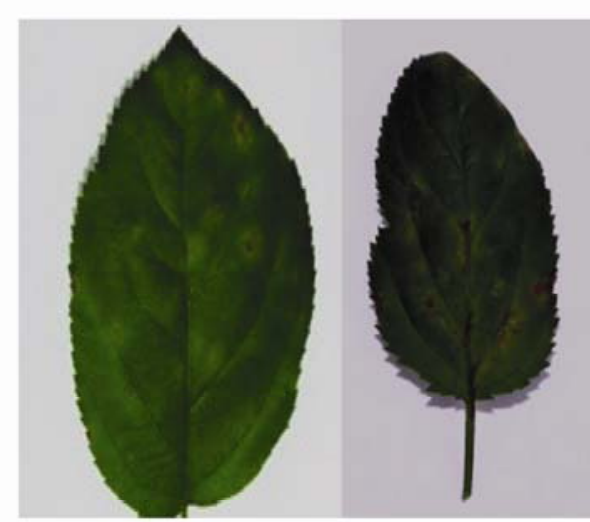

\section{Galaxy

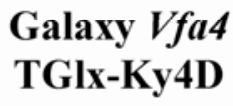

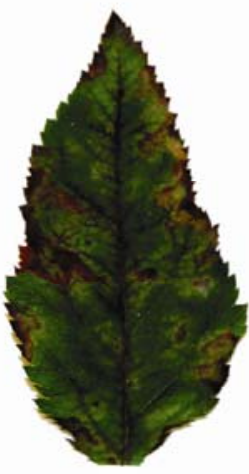

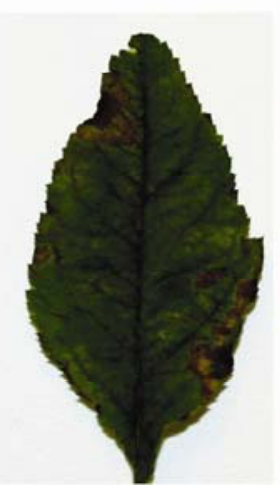

\section{Galaxy $V f a 1$ \\ TGx-1562}

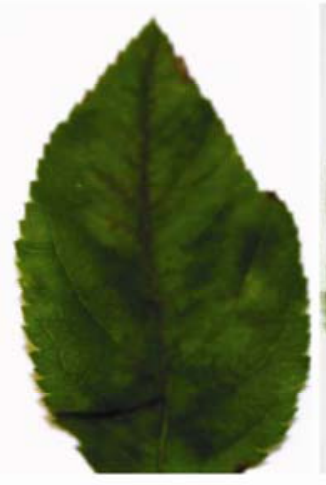

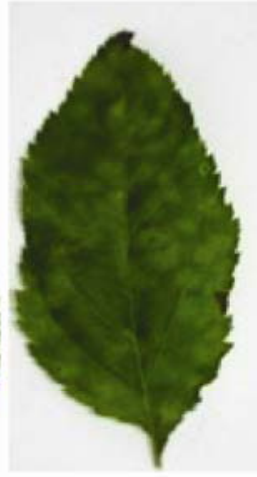

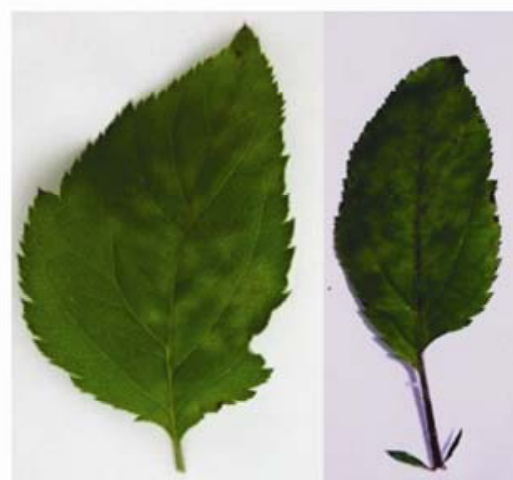

Fig. 1. Leaf symptoms, 21 days after inoculation with Venturia inaequalis conidia, on various transformed apple lines. Typical symptoms on transformed lines TMcI-1577 and Gx-KY4D carrying Vfa4, transformed lines TMcI-1578 and TGx1562 carrying the Vfal transgene, and TMcI1580 and TGx1568 carrying the $V f a 2$ transgene. Symptoms on the scab-susceptible cvs. Galaxy and McIntosh used as control (nontransformed). 
tivars and shown to confer scab resistance when driven by the strong constitutive Cauliflower mosaic virus (CaMV) 35S promoter (Belfanti et al. 2004).

In this study, a detailed analysis was undertaken to reveal the distinct functions of each of the three full-length $V f a$ paralogs in the resistance response of apple to $V$. inaequalis by complementary tests. Intact genomic candidate genes of each of the $V f a$ paralogs were cloned into the binary vector pCAMBIA2301, including the intact $\mathrm{ORF}$, at least $2 \mathrm{~kb}$ of the promoter sequence, and $3^{\prime}$ untranslated regions (UTR). The three constructs were introduced into the scab-susceptible apple cvs. Galaxy (Gx) and McIntosh (McI) via Agrobacterium-mediated transformation. Transformed apple lines were subjected to a series of tests to confirm their gain of exogenous genes, expression levels, and resistance specificities following inoculation with $V$. inaequalis.

\section{RESULTS}

\section{Transformation efficiency and ploidy level.}

Transformation of Agrobacterium tumefaciens EHA105 $\mathrm{pCH} 32$, containing each of the binary vectors $\mathrm{pVfa} 1, \mathrm{pVfa} 2$, or pVfa4 harboring Vfal, Vfa2, and Vfa4 paralogs, respectively, was conducted. Using 50 leaf explants each of $\mathrm{Gx}$ and $\mathrm{McI}$ apple genotypes for transformation with each of the Vfal, $V f a 2$, and Vfa4 constructs produced 4, 5, and 9 Gx-transformed lines, respectively, and 3, 4, and 5 McI-transformed lines, respectively. The transformation efficiency, 8 to $18 \%$ for Gx and 6 to $10 \%$ for McI, was higher than those previously reported for various apple genotypes (Faize et al 2003; Puite and Schaart 1996; Szankowski et al 2003) or other Rosaceae woody plants (Malnoy et al 2003; Scorza et al 1994). Presence of each of the Vfa genes in all transformed lines, growing on selection medium, was confirmed by polymerase chain reaction (PCR) analysis and by Southern analysis. All lines amplified the corresponding amplicon for the introduced Vfa transgene. Analysis of ploidy levels, as determined by flow cytometry, confirmed that all transformed lines were diploid and similar to nontransformed $\mathrm{Gx}$ and McI.

Table 1. Pooled results of four greenhouse inoculations of apple plants 21 days post inoculation with Venturia inaequalis

\begin{tabular}{lccc}
\hline Plants & $\begin{array}{c}\text { No. of plants } \\
\text { inoculated }\end{array}$ & $\begin{array}{c}\text { Mean scab } \\
\text { infections }( \pm \mathbf{S D})^{\mathbf{a}}\end{array}$ & $\begin{array}{c}\text { No. of infected } \\
\text { leaves }( \pm \mathbf{S D})^{\mathbf{b}}\end{array}$ \\
\hline Galaxy & 15 & $2.64 \pm 0.37$ & $4.34 \pm 0.25$ \\
Vfal lines & & & \\
TGx-1562 & 11 & $0.98 \pm 0.12$ & $2.51 \pm 0.3$ \\
TGx-1563 & 8 & $1.23 \pm 0.24$ & $3.12 \pm 0.5$ \\
TGx-1566 & 7 & $1.47 \pm 0.34$ & $2.43 \pm 0.4$ \\
TGx-1567 & 10 & $1.59 \pm 0.27$ & $2.57 \pm 0.3$ \\
Vfa2 lines & & & \\
TGx-1564 & 15 & $1.18 \pm 0.11$ & $3.1 \pm 0.2$ \\
TGx-1568 & 9 & $0.97 \pm 0.09$ & $2.41 \pm 0.6$ \\
TGx-1570 & 26 & $1.65 \pm 0.45$ & $2.78 \pm 0.4$ \\
TGx-1573 & 7 & $1.67 \pm 0.33$ & $3.32 \pm 0.3$ \\
TGx-1574 & 17 & $1.38 \pm 0.26$ & $3.61 \pm 0.5$ \\
McIntosh & 18 & $2.92 \pm 0.15$ & $4.85 \pm 0.4$ \\
Vfal lines & & & \\
TMcI-1572 & 12 & $1.98 \pm 0.16$ & $3.19 \pm 0.5$ \\
TMcI-1579 & 13 & $1.89 \pm 0.21$ & $2.98 \pm 0.5$ \\
TMcI-1580 & 11 & $1.52 \pm 0.32$ & $2.80 \pm 0.5$ \\
Vfa2 lines & & & \\
TMcI-1571 & 10 & $1.98 \pm 0.12$ & $3.24 \pm 0.5$ \\
TMcI-1575 & 14 & $2.01 \pm 0.08$ & $3.55 \pm 0.5$ \\
TMcI-1576 & 12 & $1.86 \pm 0.13$ & $3.34 \pm 0.5$ \\
TMcI-1578 & 12 & $1.77 \pm 0.22$ & $3.11 \pm 0.3$ \\
\hline
\end{tabular}

\footnotetext{
${ }^{a}$ Mean scab infections (of the three most infected leaves) \pm standard deviation (SD).

${ }^{b}$ Number of infected leaves (with sporulation) per plant (mean \pm SD).
}

\section{Scab resistance evaluation.}

To assess scab resistance in transformed lines, plants were evaluated 21 days after inoculation with a mixture of races 1 to 5 of $V$. inaequalis. Disease symptoms were recorded for individual plants from each of the transformed lines for qualitative resistance reactions as well as quantitative levels of sporulation. Nontransformed cvs. Gx and McI exhibited distinct symptoms of scab infection along with moderate to heavy sporulation (Fig. 1). Gx and McI showed high susceptibility to the mixture of scab inoculum, with sporulation observed as early as 10 days following inoculation. Symptom severity peaked after 21 days, with heavy sporulation (Fig. 1) observed on all inoculated young leaves; the two nontransformed controls showed no resistance reactions (Fig. 1). Similar results were observed in transformed lines of Gx transformed with a binary vector expressing the $\beta$ glucuronidase (GUS) gene (data not shown).

Transformed plants expressing the Vfa4 transgene were as or more susceptible than control (nontransformed McI or Gx) plants (Fig. 1). In contrast, transformed plants expressing either Vfal or Vfa2 demonstrated significant resistance to V. inaequalis when compared with control plants (Table 1). Overall, most transformed lines carrying either Vfal or Vfa 2 showed no symptoms on approximately $50 \%$ of inoculated young leaves and only small chlorotic lesions after 10 days on some of the other leaves. After 21 days, these chlorotic areas became more severe, and some sporulation was observed along the midrib (Fig. 1). For transformed lines expressing either $V f a 1$ or $V f a 2$ under the control of their own promoters, both the severity and number of leaves infected were significantly lower than those of control plants (both nontransformed and those transformed with the GUS gene). Two Gx-transformed lines, TGx1562 and TGx1568, expressing $V f a 1$ and $V f a 2$ transgenes, respectively, showed less than $5 \%$ of leaves with sporulation along with fewer leaves infected when compared with the Gx control, wherein approximately $50 \%$ of leaves showed heavy sporulation (Table 2). All other transformed lines of both Gx and McI expressing either Vfal or Vfa2 also had fewer leaves infected and the level of sporulation on leaves was less than that observed on control plants.

The incidence of germinated $V$. inaequalis conidia was confirmed on leaves of both transformed lines and control plants (Table 2). Three different stages of development of the fungal pathogen were observed on upper leaf surfaces, as follows: stage 1 , no fungal development beyond appressoria and penetration peg formation; stage 2, subcuticular primary stroma formed; and stage 3, stroma development with sporulating conidiophores. For 88 and $70 \%$ of transformed Gx lines carrying either Vfal or $V f a 2$, respectively, no fungal development beyond that of appressoria and penetration peg formation (stage 1) was observed, and these were significantly higher than those for control plants (only 12\% for nontransformed Gx were rated stage 1). For McItransformed lines carrying either $V f a l$ or $V f a 2,70$ and $50 \%$ of plants, respectively, exhibited stage 1 reaction, and these were significantly higher than those of control plants (only $4.7 \%$ of nontransformed McI were rated stage 3) (Table 2). Leaves of transformed lines of both Gx and McI expressing either Vfal or $V f a 2$ showed similar frequencies of stage $2 \mathrm{~V}$. inaequalis development. The percentage of leaf area of transformed plants with the presence of stroma with sporulating conidiophores was significantly lower than that observed on control leaves (Table 1). Moreover, the amount of sporulating conidiophores on these transformed lines also was lower than that observed on control leaves. In general, transformed lines expressing $V f a l$ showed limited $V$. inaequalis development because the percentage of leaf area with stage $1 \mathrm{~V}$. inaequalis development was higher $(20 \%$ in $\mathrm{Gx}$ and $30 \%$ in McI) than that of controls as well as that of transformed lines expressing $V f a 2$. 


\section{Molecular characterization} of $\boldsymbol{V f a}$ gene expression in transformed lines.

To address the molecular basis for the observed wide range of disease susceptibility observed in $V f a$ Gx- and McI-transformed lines (carrying Vfal, Vfa2, or Vfa4), Vfa mRNA and protein levels were determined in transformed lines in the greenhouse inoculated (or noninoculated) with $V$. inaequalis and compared with those of nontransformed $\mathrm{Gx}$ and $\mathrm{McI}$ plants under the same conditions. As revealed by quantitative real-time PCR, noninoculated transformed lines displayed mRNA levels of Vfal or Vfa2 similar to those of controls (Fig. 2), except for the TGx-1568 transformed line (carrying Vfa2), which showed fivefold higher $V f a 2$ expression than that of controls. By $24 \mathrm{~h}$ after inoculation with $V$. inaequalis, levels of either Vfal or Vfa 2 mRNA in transformed lines were significantly higher than those of control plants. An increase of 5- to 10-fold and 2- to 8-fold for Vfal transgene expression in Gxand McI-transformed lines, respectively, compared with those in control plants was observed. Moreover, an increase of 4- to 30-fold and 5- to 8-fold for Vfa2 transgene expression in Gxand McI-transformed lines, respectively, compared with those in control plants also was observed.

Expression levels of $V f a l$ and $V f a 2$ were determined in all Gx-transformed lines, before and after scab inoculation, by Western blots (Fig. 3). The level of expression of Vfal transgene was significantly higher $24 \mathrm{~h}$ following inoculation with V. inaequalis than at $0 \mathrm{~h}$ (before inoculation) (Fig. 3). The antibody anti-Vfal recognized several bands in transformed lines expressing the Vfal transgene; one band was overexpressed before inoculation with $V$. inaequalis and three bands appeared to be overexpressed after inoculation. Similar results were obtained for McI-transformed lines expressing either $V f a l$ or $V f a 2$ genes under the control of their own promoters (data not shown). However, only two bands were detected in transformed lines expressing the $V f a 2$ transgene. The predicted sizes of the Vfa1 and Vfa2 protein are approximately 138 and $109 \mathrm{kDa}$, respectively. However, the sizes of the bands observed in the Western blot were lower than the sizes of the predicted proteins of either Vfal or Vfa2. This could be due to either degradation or cleavage of the protein in these transformed lines. Indeed, the addition of the size of the bands observed is almost equivalent to the predicted size for these proteins. For example, two bands corresponding to Vfa2 were detected in the transformed lines after inoculation; their sizes were approximately 70 and $32 \mathrm{KDa}$, which in sum is close to the predicted size of $109 \mathrm{kDa}$. Those bands expressed in all transformed lines before or after inoculation with $V$. inaequalis also were detected at a very low level in the Gx control following inoculation with $V$. inaequalis. This could be attributed to the fact that the antibodies were not completely specific to Vfa proteins.

\section{Copy number of T-DNA insertions.}

Using real-time PCR, the number of insertions of $V f a l$ and $V f a 2$ genes in genomes of transformed Gx lines were determined using the procedures described by Livak and associates (1995) and Livak and Schmittgen (2001). Of 15 trangenics lines analyzed for integration of either $V f a 1$ or $V f a 2$ genes, only one transformed line showed two copies of the Vfa2 transgene, whereas all other transformed lines had one complete copy of the T-DNA plasmid (Table 3). The integration of a single copy of either Vfal or Vfa2 transgenes also was confirmed in several transformed lines (TGx1564 and TGx1568 for Vfa2, and TGx1562 and TGx1568 for Vfal) by Southern blots (data not shown).

\section{DISCUSSION}

Recently, the $V f$ locus from $M$. floribunda was restricted to a 290-kb BAC contig covered by five overlapping BAC clones (Xu and Korban 2002a). Using either a chromosome landing (Xu and Korban 2002b) or chromosome walking (Vinatzer et al 2001) strategy, a cluster of four $V f$ paralogs was identified within the $V f$ locus. The four $V f$ paralogs, $V f a l$ to $V f a 4$ (referred to as Hcrvfl to Hcrvf4 by Vinatzer and associates [2001]), were predicted to encode proteins characterized with extracellular LRRs and TM domains. Alignment of coding regions between $\mathrm{cDNA}$ and genomic sequences revealed that $V f a 1, V f a 2$, and Vfa4 were intron-less genes, and exhibited a $100 \%$ match between cDNAs and genomic genes; whereas Vfa3 had a 780-bp insert that caused multiple terminations of RNA transcription (Xu and Korban 2002b).

The role of each of these various $V f$ candidate genes must be elucidated because it is not clear which of these $V f a$ members is responsible for the observed $V f$ resistance. Previously, we have determined that transcripts from all three $V f a$ genes are detected in leaves prior to fungal infection (Vinatzer et al 2001; Xu and Korban 2002b). However, Vfal and Vfa2 are highly expressed in young leaves, whereas Vfa4 is highly expressed in older leaves (Xu and Korban 2002b). Based on these

Table 2. Incidence of germinated Venturia inaequalis conidia on inoculated leaf surfaces of transformed and control plants ${ }^{\mathrm{a}}$

\begin{tabular}{|c|c|c|c|c|c|}
\hline Constructs & Transformed lines & Stage 1 & Stage 2 & Stage 3 & Total \\
\hline Galaxy & & $4.17(12.7 \%)$ & $7.50(22.8 \%)$ & $21.17(64.5 \%)$ & $32.84(100 \%)$ \\
\hline \multirow[t]{4}{*}{ Vfal } & TGx-1562 & $32.67(88.1 \%)$ & $3.15(8.5 \%)$ & $1.27(3.4 \%)$ & $37.09(100 \%)$ \\
\hline & TGx-1563 & $38.51(88.7 \%)$ & $3.54(8.2 \%)$ & $1.34(3.1 \%)$ & $43.39(100 \%)$ \\
\hline & TGx-1566 & $35.91(91.8 \%)$ & $2.76(7.1 \%)$ & $0.45(1.1 \%)$ & $39.12(100 \%)$ \\
\hline & TGx-1567 & $37.17(94.5 \%)$ & $1.83(4.7 \%)$ & $0.33(0.8 \%)$ & $39.33(100 \%)$ \\
\hline \multirow[t]{5}{*}{$V f a 2$} & TGx-1564 & $30.33(68.2 \%)$ & $10.33(23.2 \%)$ & $3.83(8.6 \%)$ & $44.49(100 \%)$ \\
\hline & TGx-1568 & $27.20(72.7 \%)$ & $9.20(24.6 \%)$ & $1.00(2.7 \%)$ & $37.40(100 \%)$ \\
\hline & TGx-1570 & $55.00(74.7 \%)$ & $13.83(18.7 \%)$ & $4.83(6.6 \%)$ & $73.67(100 \%)$ \\
\hline & TGx-1573 & $22.76(72.2 \%)$ & $5.98(19 \%)$ & $2.76(8.8 \%)$ & $31.50(100 \%)$ \\
\hline & TGx-1574 & $18.50(69.8 \%)$ & $5.67(21.4 \%)$ & $2.33(8.8 \%)$ & $26.50(100 \%)$ \\
\hline McIntosh & $\ldots$ & $4.50(4.7 \%)$ & $12.30(12.8 \%)$ & $79.80(82.6)$ & $96.60(100 \%)$ \\
\hline \multirow[t]{2}{*}{$V f a 1$} & TMcI-1579 & $68.31(65.9 \%)$ & $21.29(20.5 \%)$ & $14.00(13.5 \%)$ & $103.86(100 \%)$ \\
\hline & TMcI-1580 & $70.94(70.4 \%)$ & $23.78(23.6 \%)$ & $6.06(6 \%)$ & $100.78(100 \%)$ \\
\hline \multirow[t]{4}{*}{ Vfa2 } & TMcI-1571 & $31.46(54.2 \%)$ & $14.98(25.8 \%)$ & $11.65(20 \%)$ & $58.09(100 \%)$ \\
\hline & TMcI-1575 & $34.13(52.2 \%)$ & $16.54(25.3 \%)$ & $14.76(22.5 \%)$ & $65.43(100 \%)$ \\
\hline & TMcI-1576 & $32.33(53.8 \%)$ & $15.61(25.9 \%)$ & $12.23(20.3 \%)$ & $60.17(100 \%)$ \\
\hline & TMcI-1578 & $27.82(53.8 \%)$ & $14.53(28.1 \%)$ & $9.35(18.1 \%)$ & $51.71(100 \%)$ \\
\hline
\end{tabular}

\footnotetext{
${ }^{a}$ The score for the leaf area with a different stage of development of the fungus was determined on 15 to 20 leaf discs per plant. Fungal development on leaves was determined using the three classes: stage 1, no fungal development beyond that of appressoria and penetration peg; stage 2, primary stroma expanding; and stage 3 , isolated areas of stroma with sporulating conidiophores.
} 
results combined with PCR data, Afunian and associates (2004) suggested that $V f a 4$ may be responsible for $V f$ scab resistance. However, using a transformed approach, Belfanti and associates (2004) and Barbieri and associates (2003) have found that a cDNA clone of Hcrvf2, driven by the constitutive CaMV 35S promoter, in fact confers resistance to $V$. inaequalis races 1 to 5 but not to races 6 and 7 (Silverberg-Dilworth et al. 2006). Due to these conflicting findings, and because the role of all three transcribed members of the $V f$ locus remains unclear, this study was undertaken to provide a comprehensive analysis and understanding of the $V f$ resistance mechanism in apple. Moreover, this knowledge may lead to alternative strategies for practical management of apple scab disease in the field. For the introduction and expression of such resistance genes in transformed apple lines for disease management in the field, the use of a constitutive promoter such as CaMV $35 \mathrm{~S}$ in plant cloning vectors is not desirable. In order to reduce the amount of nonplant DNA introduced into transformed apple lines, and with the aim of increasing the acceptability of genetically engineered fruit, driving the expression of Vfa genes with their own promoters would be ideal.

In this study, we expressed three $V f a$ genes (Vfal, $V f a 2$, and $V f a 4)$, under the control of their own promoters, in two scabsusceptible cultivars, Gx and McI, to determine which genes are involved in scab resistance. All transformed apple lines of both Gx and McI expressing Vfa4 were as or more susceptible
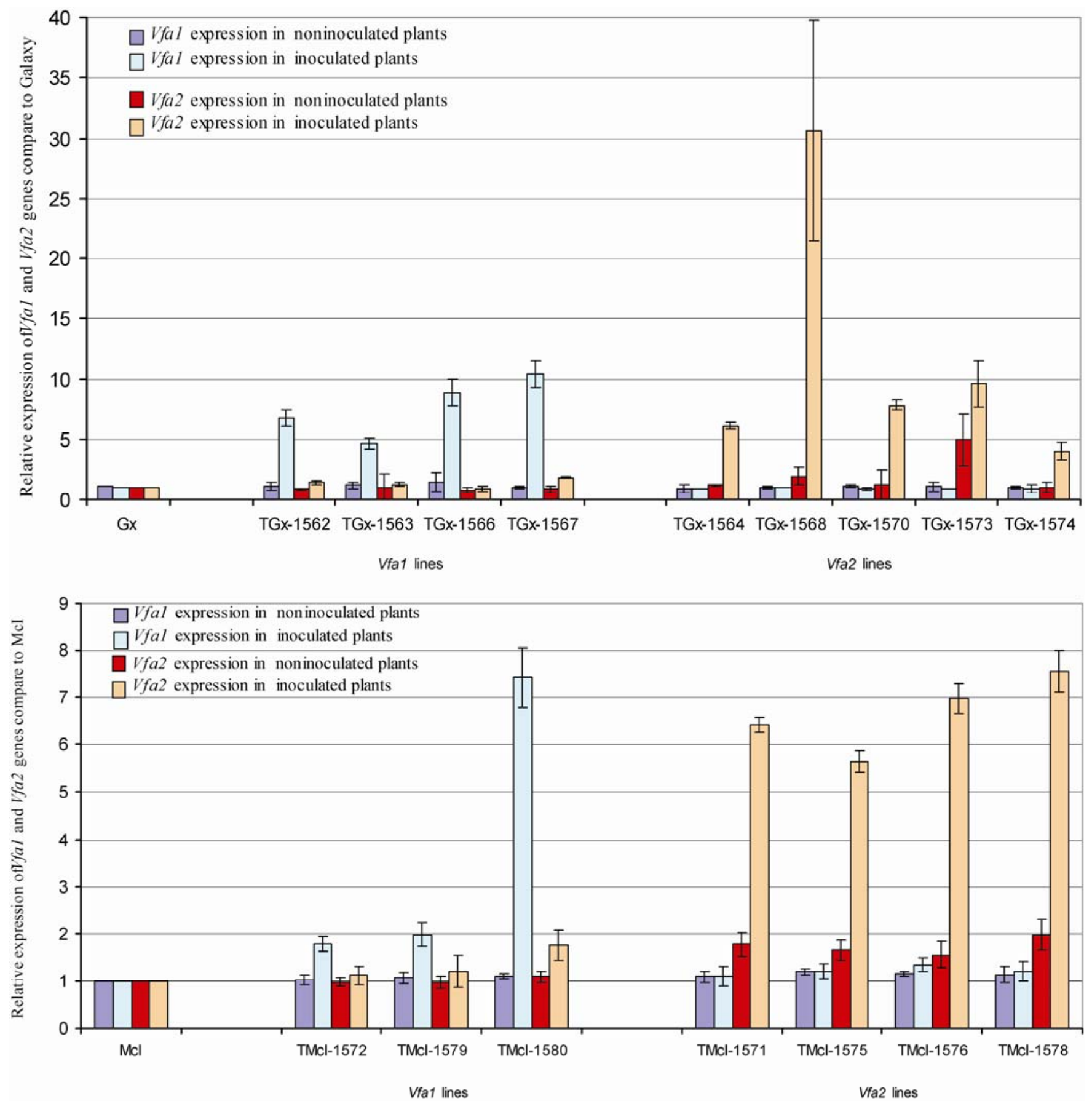

Fig. 2. Relative expression of $V f a 1$ and $V f a 2$ transgenes compared with their control, $24 \mathrm{~h}$ after inoculation with a mixture of five races (1 to 5) of Venturia inaequalis. This determination was conducted using real-time polymerase chain reaction. Each data point corresponds to the mean of six replications from two separate experiments (separate RNA extractions). 
than the controls (nontransformed Gx or McI) following inoculation with the fungal pathogen $V$. inaequalis. By contrast, transformed apple lines of both Gx and McI expressing either Vfal or Vfa2 demonstrated enhanced resistance to $V$. inaequalis when compared with control plants. Over the two tested apple cultivars, Vfal and Vfa2 transgenes decreased susceptibility to apple scab by 50 and $38 \%$, respectively. For Gx, most of the transformed lines showed significant reduction of symptoms compared with the control It appears that the transformed lines TGx1562 (Vfal) and TGx1568 (Vfa2) showed somewhat higher levels of resistance to apple scab compared with all other transformed lines. The observed differences in levels of

A

Vfa1 Gx GxI TGx-1562 TGx-15621 TGx-1563 TGX-1567

TGX-1563| TGX-1567!

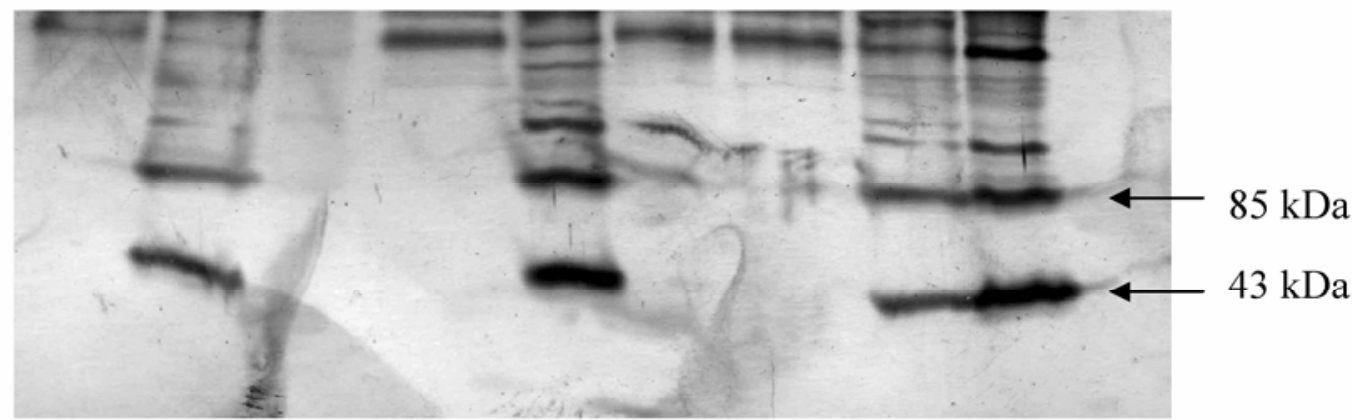

B

Gx Gx।

TGX-1564 TGX-15641 TGX-1570 TGX-1570| TGX-1573 TGX-15731

Vfa2

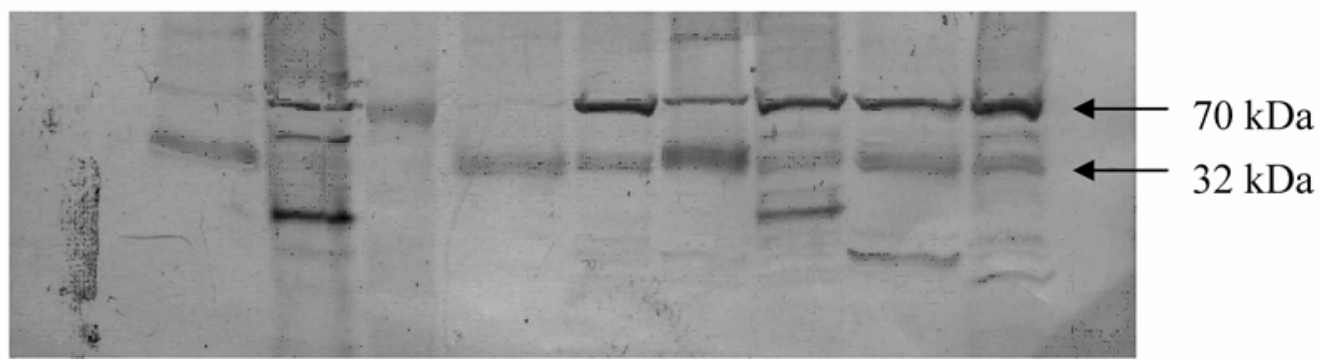

Fig. 3. Western blot analysis of A, Vfal and B, Vfa2 gene translation of greenhouse shoots from nontransformed Galaxy (Gx) and selected transformed lines before and $24 \mathrm{~h}$ after inoculation with Venturia inaequalis. The arrows indicate the band corresponding to the Vf protein found in the Gx-transformed line expressing the Vfal gene (TGx-1562, TGx-1563, and TGx-1567) or Vf2 gene (TGx-1564, TGx-1570, and TGx-1573) before and after inoculation (I).

Table 3. Determination of transgene copy numbers in transformed apple lines, carrying either $V f a 1$ or $V f a 2$, using the $2^{-\Delta \Delta C t}$ method

\begin{tabular}{|c|c|c|c|c|c|c|}
\hline Copy number, lines & Transgenes & $\mathrm{Ct}$ of transgene $\mathrm{a}^{\mathrm{a}}$ & Ct of EF & $\begin{array}{c}\Delta \mathrm{Ct}(\mathrm{Ct} \text { lines }-\mathrm{Ct} \\
\text { transformed } \mathrm{EF})\end{array}$ & $\Delta \Delta \mathbf{C t}^{\mathrm{b}}$ & $\begin{array}{c}\text { Copy number } \\
\qquad\left(2^{-\Delta \Delta C t}\right)^{c}\end{array}$ \\
\hline \multicolumn{7}{|l|}{ Vfal } \\
\hline Galaxy & & $23.7 \pm 0.6$ & $22.3 \pm 0.1$ & 1.4 & $\ldots$ & $\ldots$ \\
\hline TGX-1562 & Vfal & $22.8 \pm 0.2$ & $21.6 \pm 0.2$ & 1.2 & -0.2 & 1.2 \\
\hline TGx-1563 & Vfal & $23.1 \pm 0.1$ & $21.9 \pm 0.3$ & 1.2 & -0.2 & 1.2 \\
\hline TGx-1566 & Vfal & $22.5 \pm 0.3$ & $21.5 \pm 0.1$ & 1 & -0.4 & 1.3 \\
\hline TGx-1567 & Vfal & $23.8 \pm 0.1$ & $22.4 \pm 0.2$ & 1.4 & 0 & 1 \\
\hline McIntosh & & $20.3 \pm 0.4$ & $19.1 \pm 0.1$ & 1.2 & $\ldots$ & $\ldots$ \\
\hline TMcI-1572 & Vfal & $19.6 \pm 0.2$ & $18.7 \pm 0.4$ & 0.9 & -0.3 & 1.2 \\
\hline TMcI-1579 & Vfal & $19.6 \pm 0.3$ & $18.5 \pm 0.2$ & 1.1 & -0.1 & 1.1 \\
\hline TMcI-1580 & Vfal & $19.4 \pm 0.1$ & $18.4 \pm 0.3$ & 1 & -0.2 & 1.2 \\
\hline \multicolumn{7}{|l|}{ Vfa2 } \\
\hline Galaxy & & $23.7 \pm 0.6$ & $22.3 \pm 0.1$ & 1.4 & $\ldots$ & $\ldots$ \\
\hline TGx-1564 & Vfa2 & $22.5 \pm 0.5$ & $21.3 \pm 0.2$ & 1.2 & -0.2 & 1.2 \\
\hline TGX-1568 & Vfa2 & $22.9 \pm 0.3$ & $21.2 \pm 0.4$ & 1.7 & 0.3 & 0.8 \\
\hline TGX-1570 & Vfa2 & $22.8 \pm 0.3$ & $22.2 \pm 0.2$ & 1.6 & 0.2 & 0.9 \\
\hline TGX-1573 & Vfa2 & $22.6 \pm 0.2$ & $21.2 \pm 0.3$ & 1.4 & 0 & 1 \\
\hline TGX-1574 & Vfa2 & $22.8 \pm 0.1$ & $22.3 \pm 0.1$ & 1.5 & 0.1 & 0.9 \\
\hline McIntosh & & $24.4 \pm 0.4$ & $19.1 \pm 0.1$ & 1.2 & $\ldots$ & $\ldots$ \\
\hline TMcI-1571 & Vfa2 & $23.1 \pm 0.2$ & $22.2 \pm 0.2$ & 0.9 & -0.3 & 1.2 \\
\hline TMcI- 1575 & Vfa2 & $24 \pm 0.3$ & $22.4 \pm 0.1$ & 1.6 & 0.4 & 0.8 \\
\hline TMcI-1576 & Vfa2 & $23.8 \pm 0.5$ & $22.2 \pm 0.2$ & 0.6 & -0.6 & 1.5 \\
\hline TMcI-1578 & Vfa2 & $22.6 \pm 0.4$ & $22.6 \pm 0.6$ & 0 & -1.2 & 2.3 \\
\hline
\end{tabular}

${ }^{\mathrm{a}} \mathrm{Ct}=$ threshold cycle.

${ }^{\text {a }} \Delta \Delta \mathrm{Ct}=\Delta \mathrm{Ct}_{\text {sample }}-\Delta \mathrm{Ct}_{\text {control (Galaxy or McIntosh) }}$.

${ }^{b}$ Base 2 is valid if all polymerase chain reactions have an efficiency of 1.0. 
scab resistance among the different transformed lines most likely are attributable to differences in T-DNA integration sites because these may modify levels of transgene expression (Kumar and Fladung 2001) and subsequent resistance responses.

The results obtained in this study confirm involvement of $V f a 2$ in the resistance to apple scab, as previously reported by Belfanti and associates (2004). However, differences in scab resistance responses were detected, whereby a higher level of resistance was reported by Belfanti and associates (2004) than observed in this study. Because both studies involved transformation of similar apple genotypes, cvs. Gala (Belfanti et al. 2004) and Gx, we assume that the use of the strong constitutive promoter CaMV $35 \mathrm{~S}$ by Belfanti and colleagues versus our use of the native $V f a 2$ promoter may explain these observed differences. Moreover, in our study, transformed lines of McI also have provided similar results to those detected in transformed $\mathrm{Gx}$, thus confirming the validity of our resistance reactions using constructs carrying a genomic clone of Vfa 2 driven by its own native promoter. The partial resistance observed can be explained by a dose effect of $V f$. Indeed, in classical breeding, genotypes homozygous for $V f(2 \times V f 1$ and $2 \times$ $V f 2)$ generally are more resistant than genotypes that have only one copy of $V f(1 \times V f 1$ and $1 \times V f 2)$. When we correlated the mRNA level of expression of $V f$ with the level of scab infection, the increased resistance was due to a dose effect of $V f(R$ $=-0.71, P<0.001$ for $V f 1$ and $R=-0.66 P<0.001$ for $V f 2$ ). However, if this hypothesis is true, the spectrum of resistance of $V f 1$ and $V f 2$ should be the same. Therefore, it will be interesting to test the lines transformed with different genes by inoculation with different races of $V$. inaequalis.

Another hypothesis to explain why $V f a 1$ or $V f a 2$ does not provide the high level of resistance usually seen in apple cultivars that contain $V f$ through classical breeding could be due to the fact that these $V f$ cultivars have both the $V f a l$ and the $V f a 2$ genes, and the transformed plants tested have only Vfal or Vfa2. Other possible explanations are the high density of conidia used in the inoculum $\left(2.7 \times 10^{7}\right.$ conidia/ml $)$ or a mutation of the $V f a l$ and/or $V f a 2$ during the different steps of the transformation process. It will be interesting in future to investigate these possibilities.

In this study, the observed host-pathogen interactions suggest that the interaction of $\mathrm{V}$. inaequalis with Malus genotypes supports Flor's (1956) gene-for-gene hypothesis. In fact, our data clearly demonstrate that, when transformed with either Vfal or Vfa2 genes, transformed lines of the scab susceptible cvs. Gx and McI can develop an incompatible reaction with a mixed-strain inoculum of $V$. inaequalis. This indicates that two of the three resistance genes of the $V f$ locus are capable of triggering a resistance response. The identification of many $R$ genes (over 50) and, in many cases, also the corresponding Avr genes has contributed greatly to our overall understanding of the molecular basis of the gene-for-gene disease resistance response (Martin et al. 2003). Previously, it has been reported that $C f$ genes confer resistance to the biotrophic leaf fungal Cladosporium fulvum in tomato plants. Over the years, a number of $C f$ genes have been cloned, and these have been classified into two large families (Kruijt et al. 2005). For example, each of the two resistance genes $C f-4$ and $C f-9$ is found within a cluster of five ORF and, within each cluster, two ORF confer resistance to $C$. fulvum ( $C f-4$ and $H c r 9-4 E$, and $C f-9$ and $H c r 9$ $9 A$ or Hcr9-9B, respectively) (Rivas and Colwyn 2005). Interestingly, $\mathrm{Hcr} 9-9 \mathrm{~A}$ and $\mathrm{Hcr} 9-9 \mathrm{~B}$ are active only in adult tomato plants, whereas $C f-9$ and $C f-4$ are active in young tomato seedlings as well and exhibit differential expression patterns between members of a cluster. In this study, two of the three genes of the $V f$ cluster are involved in resistance to apple scab; thus, the observed differences in expression patterns between tissues cannot be attributed to differences in age of tissues because both genes involved in scab resistance, Vfal and $V f a 2$, are appropriately expressed in immature apple leaves but less so in mature leaves (Xu and Korban 2002b). Although differences in expression have been observed in transformed lines carrying the $V f a 4$ transgene, this gene is not involved in scab resistance.

A recent evolutionary analysis of the $V f$ gene family has suggested that $V f a$ genes have evolved mainly by divergent somatic variation (Xu and Korban 2004), because no sequence exchange between the four homologs is detected. It is proposed that two sequential duplication events may have generated the four $V f$ genes from a single $V f$ progenitor gene. A divergence point located approximately $300 \mathrm{bp}$ upstream of the start codon of the $V f$ genes has delimited two classes of sequences. In one class, Vfal and $V f a 2$, the two paralogs are nearly identical within sequenced fragments, except for the promoter region. In a second class, Vfa3 and $V f a 4$, the other two paralogs continue to be highly homologous until they reach a second divergence point located approximately $1.3 \mathrm{~kb}$ upstream of the start codon (Xu and Korban 2004). The formation of the closely related pairs Vfal/ Vfa2 and Vfa3/Vfa4 may be involved in the coevolution with Avr genes of $V$. inaequalis and may explain our findings that only the $V f a l / V f a 2$ gene pair is involved in the resistance response to $V$. inaequalis. The promoter regions of $V f a 1 / N f a 2$ genes have included some nucleotide substitutions (Xu and Korban 2004) which may be attributed to differences in specificities to different races of $V$. inaequalis; therefore, this may lead to development of resistance specificity. The question arises whether $V f a l$ and $V f a 2$ recognize the same elicitor or different elicitors. Inoculating lines transformed with $V f a l$ and $V f a 2$ singly with individual races of $V$. inaequalis may help answer this.

The cloning of the apple scab resistance genes from wild apple genotypes into commercial apple genotypes represents a step toward enhancing the resistance of scab-susceptible apple genotypes. Expression of $V f a$ genes under the control of their own promoters will increase the resistance to scab in elite commercial apple cultivars while maintaining their outstanding fruit characteristics. The integration of apple genes and promoters into the genome of susceptible cultivars is the first step toward the commercialization of transformed resistant plants. However, the use of a transformation procedure such as the markerless DNA transformation technology, where no selectable marker is used to select the transformed lines (Malnoy et al. 2007), will facilitate commercialization of transformed apple cultivars. This likely will improve the acceptability of genetically engineered apple fruit by consumers, growers, and regulatory agencies, compared with the use of effective genes and antibiotic resistance marker genes from other organisms. Following the proposal of Schouten and associates (2006), these genetically engineered apple fruit should not be considered transformed, but rather as intragenic plants (Nielsen 2003) or cisgenic (Schouten et al. 2006), which may facilitate their approval by the present system for deregulation.

\section{MATERIALS AND METHODS}

\section{Vfa constructs.}

Previously, the BAC clone M-61-M-16 was found to cover the Vfal and Vfa2 paralogs while another BAC clone, G7-C18 , covered the $V f a 3$ and $V f a 4$ paralogs. DNAs from these two BAC clones were isolated and purified via an equilibrium centrifugation in CsCl-ethidium bromide gradients. BAC DNA (4 $\mu \mathrm{g})$ was partially digested with 0.5 units of Sau3AI in a volume of $150 \mu \mathrm{l}$, and digested fragments were separated on $1 \%$ agarose gel. The gel band corresponding to $10-$ to $15-\mathrm{kb}$ fragments was sliced from the gel and purified with QIAEX II Gel 
Extraction kit (Qiagen, Hilden, Germany). After they were checked on $1 \%$ agarose gel, Sau3A-digested DNA fragments were ligated into a BamHI-digested binary vector pCAMBIA2301. Screening of positive clones was conducted using both the nested-common and Vfa-specific primers. Clones containing the full paralogs, including at least the $2 \mathrm{~kb}$-promoter, entire ORF, and at least 1-kb 3' UTR, were selected and their inserts sequenced. Based on sequence analysis, Vfa3 was found to be interrupted by a transposon-like sequence and was deemed nonfunctional (Xu and Korban 2002b). As a consequence, three $V f a$ constructs, covering the full $V f a 1$, Vfa2, and Vfa4 paralogs, were used for apple transformation. (Fig. 4).

\section{Plant material and transformation.}

The apple cvs. Gx and McI were selected as plant receptors for this study because both can be transformed at high efficiencies (Borejsza-Wysocka et al. 1999; Norelli et al. 1996).

Young leaf segments were excised from in vitro-grown shoots of both Gx and McI 3 weeks following subculture. Apple transformation was carried out as previously described (Borejsza-Wysocka et al. 1999; Norelli et al. 1996) using A. tumefaciens strain EHA105 containing one of the following four binary vectors: pBI121, pCAMBIA2301Vfa1, pCAMBIA2301Vfa2, or pCAMBIA2301Vfa4.

DNA was isolated from the youngest leaf of putative transformed plants and nontransformed control plants following the procedure of the "Nucleon phytopure plant and fungal DNA extraction kits" (Amersham, Piscataway, NJ, U.S.A.) and PCR was performed as described by Bolar and associates (1999). In order to check for the presence of promoter- $V f a$ fusions, specific primers were designed to amplify a fragment of the Vfa promoter region and of the Vfa sequence (Table 4). Nontransformed Glx, nontransformed McI, and transformed clones were propagated in vitro as described by Norelli and associates (1996). Acclimation of plants was performed as described by Bolar and associates (1998).

\section{Determination of ploidy level.}

Ploidy levels in transformed and nontransformed clones were estimated by DNA flow cytometry. Nuclei were isolated from in vitro-grown leaves by manual chopping of leaves with a razor blade directly into the buffer as recommended by the manufacturer (Partec, Münster, Germany). Following the addition of 4,6-diamino-2-phenyl-indole-dihydrochloride (2\% vol/ vol) and filtration through a $20-\mu \mathrm{m}$ nylon mesh, the mixture was analyzed using a Partec II flow cytometer (Partec).

\section{DNA extraction and detection of T-DNA integration.}

DNA from transformed lines and nontransformed control was isolated using the "Nucleon phytopure plant and fungal DNA extraction kits" protocol (Amersham).

\section{Real-time PCR analysis.}

Real-time PCR analyses were performed with a IQ 5 realtime PCR detection system (Bio-Rad, Hercules, CA, U.S.A.) in a $25-\mu 1$ volume containing $1 \mu \mathrm{l}$ of $10 \mathrm{ng}$ of DNA sample or

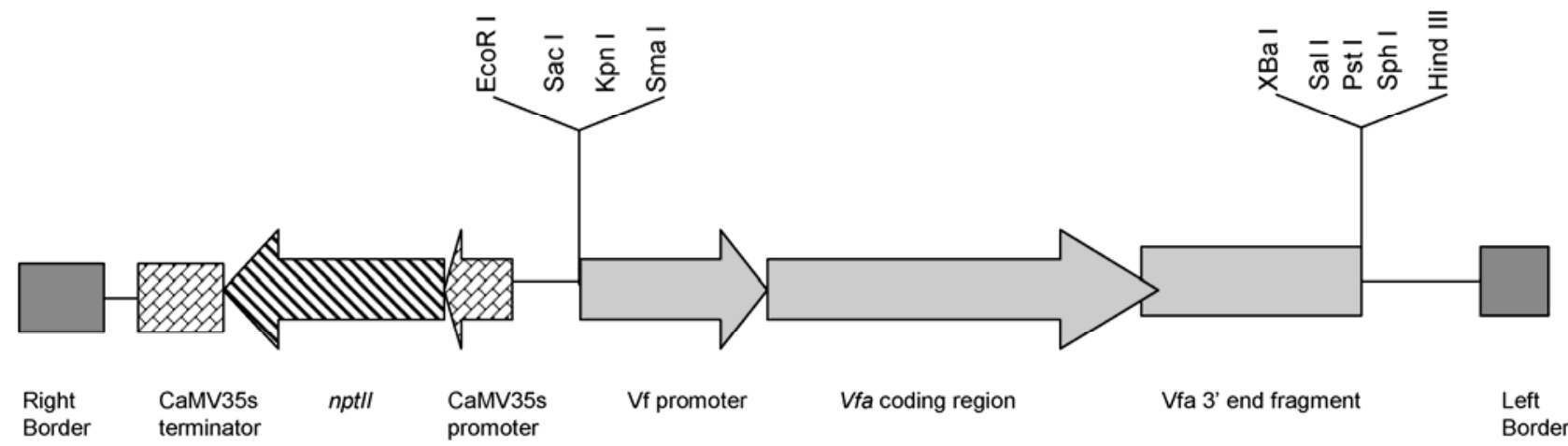

Fig. 4. Schematic diagram of the T-DNA region from the binary vectors pCAMBIA2301Vfa.

Table 4. Primers and probes

\begin{tabular}{|c|c|c|c|}
\hline Primers, probes & Sequences & Temperature $\left({ }^{\circ} \mathbf{C}\right)$ & Size (bp) \\
\hline \multicolumn{4}{|l|}{ Primers } \\
\hline \multicolumn{4}{|l|}{ Gene expression ${ }^{\mathrm{a}}$} \\
\hline Vfa1-F & AATTCTTTGATGCCGAGGTG & 54 & 537 \\
\hline Vfa1-R & TTCGAAGATTTCGGATGGTC & $\ldots$ & $\ldots$ \\
\hline Vfa2-F & GTTGCTGGTCCTTCTTCAGC & 54 & 658 \\
\hline Vfa2-R & AGTCCAGACGCAACCATACC & e & \\
\hline EF-F & ATTGTGGTCATTGGTCATGT & 54 & 700 \\
\hline EF-R & CCAATCTTGTAGACATCCTG & $\ldots$ & $\ldots$ \\
\hline \multicolumn{4}{|l|}{ Copy number ${ }^{b}$} \\
\hline Vfa1 F RT & GGTGAAATATCGAGTTCC & 50 & 93 \\
\hline Vfa1 R RT & CAAAGAATTTGGGATTTT & $\ldots$ & $\ldots$ \\
\hline Vfa2 F RT & TTGAACAATCTCGAGTCCTTA & 50 & 99 \\
\hline Vfa2 R RT & GAATGGGACCTGATATTGAA & $\ldots$ & \\
\hline EF F RT & AGTATGCCTGGGTGTTGGAC & 50 & 107 \\
\hline EF R RT & AACTTCCACAGGGCAATGTC & $\ldots$ & $\ldots$ \\
\hline \multicolumn{4}{|c|}{ ค1 } \\
\hline Vfal & FAM-CATGACATCCCTTGTCAATCTTAACTTAGAAAATAATCAG-TAMRA & $\ldots$ & $\ldots$ \\
\hline Vfa2 & FAM-GGCAATGCCTTACGCTTAAAAGTTTAAGGCACTTTGATC-TAMRA & $\ldots$ & $\ldots$ \\
\hline$E F$ & TET-GCTCAAGGCTGAGCGTGAACG-TAMRA & $\ldots$ & $\ldots$ \\
\hline
\end{tabular}

\footnotetext{
${ }^{\text {a }}$ Primers for quantification of $V f a$ gene expression levels

${ }^{\mathrm{b}}$ Primers for determination of copy number of transgene.
} 
$3 \mu \mathrm{l}$ of cDNA, and $20 \mu \mathrm{l}$ of the PCR master mixture. The PCR master mixture contained the following: $0.5 \mu \mathrm{M}$ each reverse and forward primer, $0.2 \mathrm{mM}$ dNTPs, $5 \mathrm{mM} \mathrm{MgCl}_{2}, 100 \mathrm{nM}$ labeled probes for the determination of the copy number or $2 \times$ SYBR Green I (Molecular Probes, Eugene, OR, U.S.A.) for the quantification of the Vf expression, $2.5 \mu \mathrm{l}$ of Hot start Taq polymerase buffer (10x), and $0.2 \mu$ l of Takara Ex Taq Hot start Version (Takara, Madison, WI, U.S.A.). PCR conditions for amplifying $V f a$ DNA were $95^{\circ} \mathrm{C}$ for $1 \mathrm{~min}$, then 50 cycles of $95^{\circ} \mathrm{C}$ for $10 \mathrm{~s}$ and $50^{\circ} \mathrm{C}$ for $60 \mathrm{~s}$; and for $E F$ gene were $95^{\circ} \mathrm{C}$ for $1 \mathrm{~min}$, then 50 cycles of $95^{\circ} \mathrm{C}$ for $10 \mathrm{~s}$ and $54^{\circ} \mathrm{C}$ for $60 \mathrm{~s}$.

Using a standard curve for each of the experiments, the quantity of cDNA present at the beginning of the reaction was determined. PCR fragments of $E F$ and the Vfas were purified and used to established a standard curve. All primers used are listed in Table 4.

The threshold cycle $(\mathrm{Ct})$ value was determined by using the instrument's software and was adjusted manually, as necessary. The probe for $V f a$ genes was labeled at the $5^{\prime}$ end with FAM as a reporter and at the $3^{\prime}$ end with TAMRA as a quencher.

The transgene copy number was calculated according to the $2^{\Delta \Delta \mathrm{Ct}}$ method (Livak and Schmittgen 2001; Livak et al. 1995), which has been used recently (Ingham et al. 2001; Li et al. 2004). The $\mathrm{Ct}$ value difference $(\Delta \mathrm{Ct})$ between EFCt and Vfal or $V f a 2 \mathrm{Ct}$ of each reaction was used to normalize the level of total nucleic acids. As long as the target gene ( $V f a)$ and normalizer $(E F)$ have similar dynamic ranges, quantification calculations are done by using the difference $(\Delta \mathrm{Ct})$ in $\mathrm{Ct}$ values between the target and the normalizer as follows: $\Delta \mathrm{Ct}=\mathrm{Ct}$ (target $V f a$ genes) - $\mathrm{Ct}$ (normalizer, $E F$ gene).

This value is calculated for each sample to be quantitated. Because the $E F$ gene presumably is constant relative to total genomic DNA, the $\Delta \mathrm{Ct}$ between the $V f a$ gene and the $E F$ gene in each sample corresponds to the relative quantification of the $V f a$. Finally, the copy number is calculated according to the equation copy number $=2^{\Delta \Delta \mathrm{Ct}}$, where $\Delta \Delta \mathrm{Ct}=\Delta \mathrm{Ct}$ (unknown sample) $-\Delta \mathrm{Ct}$ (reference sample).

\section{Southern blot hybridization.}

A total of $20 \mu \mathrm{g}$ of DNA was digested with the restriction enzyme HindIII or EcoRI. Digested genomic DNA from greenhouse-acclimated plants was transferred to a Hybond-N nylon membrane. This membrane was hybridized with a fluorescein-labeled probe following the standard procedure of the "DIG DNA labeling and detection kit" (Roche, Penzberg, Germany).

\section{RNA extraction.}

Total RNA (50 to $100 \mu \mathrm{g}$ ) was extracted from $0.5 \mathrm{~g}$ of young leaves excised from in vitro-grown shoots following the Agilent plant RNA isolation mini-kit (Agilent, Wilmington, DE, U.S.A.). Reverse transcription was performed using $2 \mu \mathrm{g}$ of total RNA.

\section{Protein extraction and Western blot.}

Protein extraction was carried out using $200 \mathrm{mg}$ of leaf tissue from in vitro-grown shoots of each of the transformed and control plants according to Malnoy and associates (2005). For Western analysis, 50- $\mu \mathrm{g}$ aliquots of protein extract from transformed and control plants in Laemmli buffer were separated on $16 \%$ sodium dodecyl sulfate-tricine polyacrylamide (wt/vol) gel. Following electrophoresis, protein was blotted onto Hybond $\mathrm{C}$ nitrocellulose membrane (Amersham) by passive transfer. Polyclonal rabbit anti-Vfal or anti-Vfa 2 antiserum was used. $V f a$ protein was detected with the enhanced chemiluminescence Western blotting detection system (ECL;
Amersham) using a horseradish peroxidase-labeled secondary antibody, according to the manufacturer's instructions.

\section{Plant inoculations}

with $\boldsymbol{V}$. inaequalis and scoring of symptoms.

The youngest expanded leaf of each plant was tagged and plants were inoculated with a suspension of $V$. inaequalis $(2.7$ $\times 10^{7}$ conidia $\mathrm{ml}^{-1}$ ) using an atomizer connected to a compressed air supply (Yepes and Aldwinckle 1993). A mixed inoculum of $V$. inaequalis isolates 1805-2, 1777-8, 1771-2, 1778-6, and 1810-1 (representing the five races [1 to 5] of $V$. inaequalis present in North America) was used. Plants were incubated in a mist chamber (16-h photoperiod of $40 \mu \mathrm{mol} \mathrm{m}$ $\mathrm{s}^{-1}, 18 \pm 1^{\circ} \mathrm{C}$, and $100 \%$ relative humidity) for $48 \mathrm{~h}$ and later moved to a growth chamber at $24 \pm 1{ }^{\circ} \mathrm{C}$.

Macroscopic symptoms and infection severity were evaluated on all leaves 21 days post inoculation according to the following scale: $0=<5 \%, 1=5$ to $25 \%, 2=26$ to $50 \%$, and $3=$ $>50 \%$ of leaf surface with sporulation. The number of leaves with symptoms also was determined. The median and confidence limits of three leaves with the greatest amount of infection were calculated to represent the overall response of each transformed line and each control.

The presence of $V$. inaequalis conidial (sporulating) lesions on the leaf surface of inoculated plants was assessed 3 weeks post inoculation by optical microscopy. At 21 days post inoculation, leaves were harvested and bleached for $24 \mathrm{~h}$ in a solution of acetic acid and $100 \%$ ethanol ( $\mathrm{vol} / \mathrm{vol})$. Leaves were transferred to a solution of lactophenol ( $20 \mathrm{~g}$ of phenol, 16.6 $\mathrm{ml}$ of acetic acid, $32.1 \mathrm{ml}$ of glycerol, and $20 \mathrm{ml}$ of double-distilled water) for $24 \mathrm{~h}$, followed by staining for $15 \mathrm{~min}$ with a solution of $0.5 \%$ methyl blue diluted in lactophenol. After leaves were washed with distilled water, the number of conidia and lesions was determined by microscopy.

\section{ACKNOWLEDGMENTS}

This project was supported by a grant received from the Illinois Council for Agricultural Research (C-FAR) External and Sentinel programs (to S. $\mathrm{S}$. Korban) and by a grant from New York apple growers through the New York State Apple Research and Development Program (to H. S. Aldwinckle).

\section{LITERATURE CITED}

Afunian, M. R., Goodwin, P. H., and Hunter, D. M. 2004. Linkage of Vfa4 in Malus $\times$ domestica and Malus floribunda with $V f$ resistance to the apple scab pathogen Venturia inaequalis. Plant Pathol. 53:461-467.

Aldwinckle, H. S., Norelli, J. L., and Jones, A. L. 2003. Fire blight management in the twenty-first century, using new technologies that enhance host resistance in apple. Plant Dis. 87:756-765.

Barbieri, M., Belfanti, E., Tartarini, S., Vinatzer, B., Sansavini, S. Silfverberg-Dilworth, E., Gianfranceschi, L., Hermann, D., Patocchi, A., and Gessler, C. 2003. Progress of map-based cloning of the $V f$ resistance gene and functional verification: Preliminary results from expression studies in transformed apple. HortScience 38:329-331.

Belfanti, E., Silfverberg-Dilworth, E., Tartarini, S., Patocchi, A., Barbieri, M., Zhu, J., Vinatzer, B. A., Gianfranceschi, L., Gessler, C., and Sansavini, S. 2004. The HcrVf2 gene from a wild apple confers scab resistance to a transgenic cultivated variety. Proc Natl. Acad. Sci. U.S.A. 101:886-890.

Benaouf. G., and Parisi, L. 2000. Genetics of host-pathogen relationships between Venturia inaequalis races 6 and 7 and Malus species. Phytopathology 90:236-242.

Bergelson, J., Kreitman, M., Stahl, E. A., and Tian, D. C. 2001. Evolutionary dynamics of plant R-genes. Science 292:2281-2285.

Bolar, J. P., Hanke, V., Norelli, J. P., and Aldwinckle, H. S. 1998. An efficient method to root and acclimatize micropropagated apple cultivars. HortScience 33:1251-1252.

Bolar, J. P., Brown, S. K., Norelli, J. L., and Aldwinckle, H. S. 1999. Factors affecting the transformation of Marshall McIntosh apple by Agrobacterium tumefaciens. Plant Cell Tissue Organ. Cult. 55:31-38. 
Borejsza-Wysocka, E., Norelli, J. L., Ko, K., and Aldwinckle, H. S. 1999. Transformation of authentic M.26 apple rootstock for enhanced resistance to fire blight. Acta Hortic. 489:259-266.

Bus, V. G. M., Laurens, F. N. D., Van de Weg, E. W., Rusholme, R. L., Rikkerink, E. H. A., Gardiner, S. E., Bassett, H. C. M., Kodde, L. P., and Plummer, K. M. 2005a. The Vh8 locus of a new gene for gene interaction between Venturia inaequalis and the wild apple Malus sieversii is closely linked to the Vh2 locus in Malus pumila R12740-7A. New Phytol. 166:1035-1049.

Bus, V. G. M., Rikkerink, E. H. A., Van de Weg, E. W., Rusholme, R. L., Gardiner, S. E., Bassett, H. C. M., Kodde, L. P., Parisim, L., Laurens, F. N. D., Meulenbroek, E., and Plummer, K. M. 2005b. The Vh2 and Vh4 scab resistance genes in two differential hosts derived from Russian apple R12740-7A map to the same linkage group of apple. Mol. Breed. 15:103-116.

Calenge, F., Faure, A., Goerre, M., Gebhardt, C., Van de Weg, W. E., Parisi, L., and Durel, C.-E. 2004. Quantitative trait loci (QTL) analysis reveals both broad-spectrum and isolate-specific QTL for scab resistance in an apple progeny challenged with eight isolates of Venturia inaequalis. Phytopathology 94:370-379.

Dangl, J. L., and Jones, J. D. G. 2001. Plant pathogens and integrated defence responses to infection. Nature 411:826-833.

Durel, C. E., Parisi, L., Laurens, F., Van de Weg, W. E., Liebhard, R., and Jourjon, M. F. 2003. Genetic dissection of partial resistance to race 6 of Venturia inaequalis in apple. Genome 46:224-234.

Erdin, N., Tartarini, S., Broggini, G. A. L., Gennari, F., Sansavini, S., Gessler, C., and Patocchi, A. 2006. Mapping of the apple scab-resistance gene $V b$. Genome 49:1238-1245.

Faize, M., Malnoy, M., Dupuis, F., Chevalier, M., Parisi, L., and Chevreau, E. 2003. Chitinase of Trichoderma atroviride induces scab resistance and metabolic changes in two cultivars of apple. Phytopathology 93:1496-1504.

Flor, H. H. 1956. The complementary genetic system in flax and flax rust. Adv. Genet. 8:29-54.

Guerin, F., and Le Cam, B. 2004. Breakdown of the scab resistance gene $V f$ in apple leads to a founder effect in populations of the fungal pathogen Venturia inaequalis. Phytopathology 94:364-369.

Gygax, M., Gianfranceschi, L., Liebhard, R., Kellerhals, M., Gessler, C., and Patocchi, A. 2004. Molecular markers linked to the apple scab resistance gene $V b j$ derived from Malus baccata jackii. Theor. Appl. Genet. 109:1702-1709.

Han, Y., Gasic, K., Sun, F., Xu, M., and Korban, S. S. 2007. A gene encoding starch branching enzyme I (SBEI) in apple (Malus X domestica, Rosaceae) and its phylogenetic relationship to Sbe genes from other angiosperms. Mol. Phylogenet. Evol. 43:852-863.

Hemmat, M., Brown, S. K., Aldwinckle, H. S., Mehlenbacher, S. A., and Weeden, N. F. 2003. Identification and mapping of markers for resistance to apple scab from 'Antonovka' and 'Hansen's baccata \#2'. Acta Hortic. 622:153-161.

Hulbert, S. H., Webb, C. A., Smith, S. M., and Sun, Q. 2001. Resistance gene complexes: Evolution and utilization. Annu. Rev. Phytopathol. 39:285-312.

Ingham, D. J., Beer, S., Money, S., and Hansen, G. 2001. Quantitative real-time PCR assay for determining transgene copy number in transformed plants. Biotechnology 31:132-134.

Janick, J., Cummins, J. N., Brown, S. K., and Hemmat, M. 1996. Apples. Pages 1-77 in: Fruit Breeding, Tree and Tropical Fruits. J. Janick and J. N. Moore, eds. Wiley, New York.

Jia, Y., McAdams, S. A., Bryan, G. T., Hershey, H. P., and Valent, B. 2000. Direct interaction of resistance gene and avirulence gene products confers rice blast resistance. EMBO (Eur. Mol. Biol. Organ.) J. 19:4004-4014.

Korban, S. S. 1998. What's new with disease-resistant apple cultivars. Proc Trans. Ill. Hortic. Soc. 131:74-76.

Korban, S. S., and Chen, H. 1992. Biotechnology of apples. Pages 203227 in: Biotechnology of Fruit Tree Crops. F. Hammerschlag and R. Litz, eds. CAB International, Oxford, U.K.

Kruijt M, De Kock M. D. J., and De Witt, P. J. G. M. 2005. Receptor-like proteins involved in plant disease resistance. Mol. Plant Pathol. 6:85-97.

Kumar, S., and Fladung, M. 2001. Gene stability in transgenic aspen (Populus). II. Molecular characterization of variable expression of transgene in wild and hybrid aspen. Tree Struct. Funct. 15:503-517.

Li, Z., Hansen, J. L., Liu, Y., Zemetra, R. S., and Berger, P. H. 2004. Using Real-time PCR to determine transgene copy number in wheat. Plant Mol. Biol. Rep. 22:179-188.

Liebhard, R., Koller, B., Gianfranceschi, L., and Gessler, C. 2003. Creating a saturated reference map for the apple (Malus X domestica Borkh.) genome. Theor. Appl. Genet. 106:1497-1508.

Livak, K. J., and Schmittgen, T. D. 2001. Analysis of relative gene expression data using realtime quantitative PCR and the $2 \Delta \Delta \mathrm{Ct}$ method. Methods 25:402-408.
Livak, K. J., Flood, S. J., Marmaro, J., Giusti, W., and Deetz, K. 1995. Oligonucleotides with fluorescent dyes at opposite ends provide a quenched probe system useful for detecting PCR product and nucleic acid hybridization. PCR Methods Appl. 4:357-362.

Maliepaard, C., Alston, F. H., Van Arkel, G., Brown, L. M., Chevreau, E., Dunemann, F., Evan, K. M., Gardiner, S., Guilford, P., Van Heusden, A. W., Janse, J., Laurens, F., Lynn, J. R., Manganaris, A. G., Den Nijs, A. P. M., Periam, N., Rikkerink, E., Roche, P., Ryder, C., Sansavini, S., Schmidt, H., Tartarini, S., Verhaegh, J. J., Vrielink-Van Ginkel, M., and King, G. J. 1998. Aligning male and female linkage maps of apple (Malus pumila Mill.) using multi-allelic markers. Theor. Appl. Genet. 97:60-73.

Malnoy, M., Venisse, J. S., Brisset, M. N., and Chevreau, E. 2003. Expression of bovine lactoferrin cDNA confers resistance to Erwinia amylovora in transgenic pear. Mol. Breed. 12:231-244.

Malnoy, M., Faize, M., Venisse, J. S., Geider, K., and Chevreau, E. 2005. Expression of viral EPS-depolymerase reduces fire blight susceptibility in transgenic pear. Plant Cell Rep. 23:632-638.

Malnoy, M., Borejsza-Wysocka, E., Abbott, P., Lewis, S., Norelli, J., Flaishman, M., Gidoni, D., and Aldwinckle, H. S. 2007. Genetic transformation of apple without use of a selectable marker. Acta Hortic. 738:319-322.

Martin, G. B., Bogdanove, A. L., and Sessa, G. 2003. Understanding the functions of plant disease protein. Annu. Rev. Plant Biol. 54:23-61.

Michelmore, R. W., and Meyers, B. C. 1998. Clusters of resistance genes in plants evolve by divergent selection and a birth-and-death process. Genome Res. 8:1113-1130.

Newcomb, R. D., Crowhurst, R. N., Gleave, A. P., Rikkerink, E. H. A., Allan, A. C, Beuning, L. L., Bowen, J. H., Gera E., Jamieson, K. R., Janssen, B. J., Laing, W. A., McArtney, S., Nain, B., Ross, G. S., Snowden, K. C., Souleyre, E. J. F., Walton, E. F., and Yauk, Y. K. 2006. Analyses of expressed sequence tags from apple (Malus $\mathrm{X}$ domestica). Plant Physiol. 141:147-166.

Nielsen, K. M. 2003. Transgenic organisms-time for conceptual diversification? Nature Biotechnol. 21:227-228

Norelli J L., Mills J. Z., and Aldwinckle H. S. 1996. Leaf wounding increases efficiency of Agrobacterium tumefaciens mediated transformation of apple. HortScience 31:1026-1027.

Parlevliet, J. E. 2002. Durability of resistance against fungal, bacterial and viral pathogens; present situation. Euphytica 124:147-156.

Parniske, M., HammondKosack, K. E., Golstein, C., Thomas, C. M., Jones, D. A., Harrison K., Wulff, B. B. H., and Jones, J. D. G. 1997. Novel disease resistance specificities result from sequence exchange between tandemly repeated genes at the $C f-4 / 9$ locus of tomato. Cell 91:821-832.

Patocchi, A., Bigler, B., Koller, B., Kellerhals, M., and Gessler, C. 2004. Vr2: A new apple scab resistance gene. Theor. Appl. Genet. 109:1087-1092.

Patocchi, A., Walser, M., Tartarini, S., Broggini, G. A. L., Gennari, F., Sansavini, S., and Gessler, C. 2005. Identification by genome scanning approach (GSA) of a microsatellite tightly associated with the apple scab resistance gene Vm. Genome 48:630-663.

Puite, K. J., and Schaart, J. G. 1996. Genetic modification of the commercial apple cultivars Gala, Golden Delicious and Elstar via an Agrobacterium tumefaciens-mediated transformation method. Plant Sci. 119:125-133.

Rivas, S., and Colwyn, M. T. 2005. Molecular interaction between tomato and the leaf mold pathogen Cladosporium fulvum. Annu. Rev. Phytopathol. 43:395-436.

Schouten, H. J., Krens, F. A., and Jacobsen, E. 2006. Cisgenic plants are similar to traditionally bred plants. EMBO (Eur. Mol. Biol. Organ.) Rep. 7:750-753.

Scorza, R., Ravelonandro, M., Callahan, A. M., Cordt, J. M., Fuchs, M., Dunez, J., and Gonsalves, D. 1994. Transgenic plums (Prunus domestica L.) express the plum pox virus coat protein gene. Plant Cell Rep. $14: 18-22$.

Silfverberg-Dilworth, E., Matasci, C., Walser, M., Soglio, V., Gianfranceschi, L., van de Weg, W. E., Durel, C. E., Tartarini, S., van Kaauwen, M. P. W., Kodde, L. P., Yamamoto, T., Gessler, C., and Patocchi, A. 2006. Development of a new set of apple (Malus X domestica Borkh.) microsatellite markers. Tree Genet. Genomics 2:202-224.

Song, W. Y., Wang, G. L., Chen, L. L., Kim, H. S., Pi, L. Y., Holsten, T., Gardner, J., Wang, B., Zhai, W. X., Zhu, L. H., Fauquet C., and Ronald, P. A. 1995. Receptor kinase-like protein encoded by the rice disease resistance gene Xa21. Science 27:1804-1806.

Szankowski, I., Briviba, K., Fleschhut, K., Schoenherr, J., Jacobsen, H. J., and Kiesecker, H. 2003. Transformation of apple (Malus domestica Borkh.) with the stilbene synthase gene from grapevine (Vitis vinifera L.) and a PGIP gene from kiwi (Actinidia deliciosa). Plant Cell Rep. 22:41-149.

Tatum, T., Stepanovic, S., Biradar, D. P., Rayburn, A. L., and Korban, S. S. 2005. Variation in nuclear DNA content in Malus species and cultivated 
apples. Genome 48:924-930

Vinatzer, B. A., Patocchi, A., Gianfranceschi, L., Tartarini, S., Zhang, H. B., Gessler, C., and Sansavini, S. 2001. Apple contains receptor-like genes homologous to the Cladosporium fulvum resistance gene family of tomato with a cluster of genes cosegregating with $V f$ apple scab resistance. Mol. Plant-Microbe Interact. 14:508-514.

Wang, G. L., Ruan, D. L., Song, W. Y., Sideris, S., Chen, L. L., Pi, L. Y., Zhang, S. P., Zhang, Z., Fauquet, C., Gaut, B. S., Whalen, M. C., and Ronald, P. C. 1998. Xa21D encodes a receptor-like molecule with a leucine-rich repeat domain that determines race-specific recognition and is subject to adaptive evolution. Plant Cell 10:765-779.

Xu, M. L., and Korban, S. S. 2002a AFLP-derived SCARs facilitate construction of a $1.1 \mathrm{Mb}$ sequence-ready map of a region that spans the $V f$ locus in the apple genome. Plant Mol. Biol. 50:803-818.

$\mathrm{Xu}, \mathrm{M}$. L., and Korban, S. S. 2002b. A cluster of four receptor-like genes resides in the $V f$ locus that confers resistance to apple scab disease. Genetics 162:1995-2006.
Xu, M. L., and Korban, S. S. 2004. Somatic variation plays a key role in driving the evolution of the $V f$ gene family that confer resistance to apple scab disease. Mol. Phylogenet. Evol. 32:57-65.

Xu, M. L., Song, J., Cheng, Z., Jiang, J., and Korban, S. S. 2001. A bacterial artificial chromosome (BAC) library of Malus floribunda 821 for positional cloning of the apple scab resistance gene $V f$. Genome 44:1104-1113.

Yepes, L. M., and Aldwinckle, H. S. 1993. Pathogenesis of Venturia iaaequalis on shoot tip cultures and on greenhouse grown apple cultivars. Phytopathology 83:1155-1162.

Young, N. D. 2000. The genetic structure of resistance. Curr. Opin. Plant Biol. 3:285-290.

AUTHOR-RECOMMENDED INTERNET RESOURCE

Molecular Probes: www.probes.com 